\title{
Social Kills of Undergraduates Without Mental Disorders: Academic and Socio-Demographic Variables
}

\author{
Alessandra Turini Bolsoni-Silva - Universidade Estadual Paulista Júlio Mesquita Filho, Bauru, Brasil \\ Sonia Regina Loureiro - Universidade de São Paulo, Ribeirão Preto, Brasil
}

\begin{abstract}
Literature shows a lack of studies regarding the influence of academic and socio-demographic characteristics in social skills of students without mental disorders. The aim of this work was to characterize and compare the social skills of university students without indicators of mental disorder, according to the academic and socio-demographic variables. The participants were 461 students from both genders and various areas, without mental disorders, based on the criteria of a structured clinical interview. Social skills were evaluated through the QHC-Universitários. Data was compared using statistical procedures. The students of full-time human science courses, those in the intermediate/final years and females were more skillful. The employed students from evening courses reported more skills in speaking in public, while living with other students seemed to promote more confrontation skills.
\end{abstract}

Keywords: social skills, university, mental health, demographic data

Habilidades Sociais de Universitários sem Transtorno Mental: Variáveis Acadêmicas e Sociodemográficas

\begin{abstract}
Resumo
Verifica-se, na literatura, uma carência de estudos sobre a influência de características acadêmicas e sociodemográficas para habilidades sociais de estudantes sem transtorno mental. Objetiva-se caracterizar e comparar as habilidades sociais de estudantes universitários, sem indicadores de transtorno mental, quanto as variáveis acadêmicas e sociodemográficas. Participaram, deste estudo, 461 estudantes de ambos os sexos e de áreas diversas, sem transtorno mental, a partir de critérios de uma entrevista clínica estruturada. Procedeu-se avaliação das habilidades sociais por meio do QHC-Universitários. Os dados foram comparados por procedimentos estatísticos. Os estudantes dos cursos de humanas, integrais, de anos intermediários/finais, e as mulheres mostraram-se mais habilidosos. Os estudantes de cursos noturnos e que trabalhavam relataram mais habilidades no falar em público; morar em república pareceu promover mais habilidades de enfrentamento.

Palavras-chaves: habilidades sociais, universidade, saúde mental, dados demográficos
\end{abstract}

\section{Habilidades Sociales de Universitarios sin Trastorno Mental: Variables Académicas y Sociodemográficas}

\begin{abstract}
Resumen
Existen pocos estudios sobre la influencia de las características académicas y sociodemográficas en las habilidades sociales de estudiantes universitarios sin trastorno mental, por lo tanto el objetivo de este estudio se remite justamente a este tema. Participaron 461 estudiantes de ambos sexos y diferentes áreas, sin trastorno mental, a partir de criterios de una entrevista clínica estructurada. Las habilidades sociales fueron evaluadas a través del QHC-Universitarios y los datos se compararon mediante procedimientos estadísticos. Los estudiantes de cursos de humanidades, integrales, de años intermedios o finales; y las mujeres, se mostraron más habilidosos. Los estudiantes de cursos nocturnos y que trabajaban demostraron más habilidades para hablar en público; y el hecho de vivir en residencias estudiantiles parece promover mayores habilidades de enfrentamiento.

Palabras clave: habilidades sociales, universidad, salud mental, datos demográficos
\end{abstract}

Being admitted at a university is a unique experience since it brings new challenges in this phase of life and they request special repertories from university students. The efficiency and adaptation to those requests are dependent on how prepared students are for such performance (Facundes \& Ludermir, 2005; Ribeiro \& Bolsoni-Silva, 2011).

According to Backer (2003), half of students has difficulties to adapt to the environment of being part of a higher education institution and abandon the course, which shows the necessity for universities to prepare their students to face the proper demands of the university context. Researches have confirmed that academic lives that do not guarantee good quality of life, resulting in stressful experiences, may favor the appearance of mental disorders as well as affect academic achievement (Backer, 2003; Cole, Lazarick \& Howard, 1986; Hussain, Guppy, Robertson \& Temple, 2013; Ramírez, Hernández \& García-Campayo, 2009; Shamsuddin et al., 2013; Wristen, 2013). Accordingly, mental health resources may be taken as indicators of adaptation.

Likewise, social skills have been considered favoring resources to adaptation in different contexts of life (Del Prette \& Del Prette, 2013). Social skills are defined by Del Prette and Del Prette (2013) as “... a 
good repertory of social skills illustrates the quality of social relations, with contributions to personal satisfaction, professional realization and quality of life" (p. 48), which contributes to better mental and physical health. The authors add that, on the other hand, deficits in social skills tend to be associated to interpersonal conflicts and losses in quality of life and mental health. For Del Prette and Del Prette (2013) behaviors such as communicating, having civility, assertiveness, empathy, work social skills and expressing positive feelings are examples of Social Skills. Thus, we could conjecture that the presence of good resources of university students' mental health is related to a positive repertory of social skills.

University students' social skills have been the object of several studies particularly regarding romantic (Del Prette, Del Prette, \& Barreto, 2006) and family relationships (Ribeiro \& Bolsoni-Silva, 2011), both as research themes and difficulties. As behaviors or class answers we may mention: expressing positive feelings (Bandeira, Rocha, Freitas, Del Prette, \& Del Prette, 2006; Bolsoni-Silva, Loureiro, Rosa, \& Oliveira, 2010; Ribeiro \& Bolsoni-Silva, 2011); expressing negative feelings (Bandeira et al., 2006; Bolsoni-Silva et a., 2010; Ribeiro \& B olsoni-Silva, 2011); expressing opinions (Bolsoni-Silva et al., 2010; Ribeiro \& Bolsoni-Silva, 2011); requesting behavior changes (Bandeira et al., 2006); communicating (Bolsoni-Silva et al., 2010); resolving conflicts (Bolsoni-Silva et al., 2010); handling criticism (Ribeiro \& Bolsoni-Silva, 2011); and speaking in public (Ribeiro \& Bolsoni-Silva, 2011).

Regarding behavior by analyzing the referred study data we verified that expressing positive and negative feelings, requesting behavior changes, speaking in public and handling criticism were considered the highest deficits observed in the university student's repertory. Several variables have been related to university students' social skills. Therefore we will present as follows studies that approached the academic and socio-demographic variables.

Regarding the academic variables, related to the years that students had been attended, Bolsoni-Silva, Loureiro, Rosa, and Oliveira (2010) developed a transversal study with university students from the $1^{\text {st }}, 2^{\text {nd }}$ and $3^{\text {rd }}$ years, and they identified that the second-year students were more skillful expressing negative feelings and speaking in public - presenting seminars. Their study goal was verifying how the university years have influenced in the acquisition of social skills. Similar findings were also identified in a sample of Turkish students, where second-year students were more skillful than the beginners of the first-year (Al-Alawneh, Meqdadi, Al-Refai, Khdair, \& Malkawi, 2011).

The year-course and the kind of course also were subjects of this study, as significant variables of mental health, as reported by Cerchiari, Caetano and Faccenda (2005). They identified higher predominance of disturbances in fourth and fifth-year students - Nursing and Computer Science. Neves and Dalgalarrondo (2007) studied the predominance of mental disorders by area of course and identified high predominance of disturbances in students from area of health (56.3\%) and from area of human and art (68.1\%), at the same time that basic, exact and technological sciences presented low predominance (4.7\%). Al-Alawneh, Meqdadi, AlRefai, Khdair, and Malkawi (2011) verified that human science students were more skillful in working ingroup skills than exact science students. Bolsoni-Silva et a. (2010) compared full-time and evening courses, although in a preliminary manner, and verified that the students attending full-time course - Industrial Design students - were more skillful expressing positive feelings and handling criticism.

The nature of the activities developed and the activities cargo during graduation were approached by Facundes and Ludermir (2005) that identified in Medicine, Nursing, Odontology and Physical Education students of a university in Pernambuco that the activities supercargo and working more than thirty hours per weak were variables related to higher predominance of Common Mental Disorders (CMD). In addition, they verified that activities that involved patient's practices, particularly for Medicine students, were the ones identified as tension sources.

Regarding socio-demographic variables, the following authors confirm that females are inclined to developing mental disorders (Adlaf, Gliksman, Demers, \& Newton-Taylor, 2001; Cerchiari, Caetano, \& Faccenda, 2005; Neves \& Dalgalarrondo, 2007), as well as seeking a psychological service (Peres, Santos, \& Coelho, 2004). On the other hand, some studies have demonstrated that women are more skillful than men (Al-Alawneh et al., 2011; Bolsoni-Silva et al., 2010; Johansson, Carlbring, Heedman, Paxling, \& Andersson, 2013; Ozben, 2013), or yet that women and men have presented skills in different repertories (Al-Alawneh et al., 2011; Avsar \& Kuter, 2007; Bolsoni-silva et al, 2010).

Bolsoni-Silva et al. (2010) identified that women were more skillful in interactions with boyfriends and men in interactions with colleagues. Additionally women 
were more skillful in expressing positive feelings, in confrontation skills - expressing negative feelings and handling criticism - and speaking in public. Likewise, Ozben (2013) identified, with a sample of 525 Turkish university students, that women were more skillful, had more satisfaction with life and were less lonely than men. Al-Alawneh et al. (2011) described the skills of working in team, with a sample of 270 university students from Jordan, and verified that women were more skillful in an interpersonal point of view and men more qualified in leadership skills. Avsar and Kuter (2007) identified, with a sample of 208 Turkish students, by evaluating men and women social skills, that men were more skillful in emotional control and women in sensitiveness and emotional expressiveness.

Cerchiari et al. (2005) declared that living with family, as well as being part of ethnic majority, working with a payment and being married were the demographic variables that favored the university student's psychological welfare. However, living with other students or other people was related as risk factors to mental health. Conversely, Adlaf, Gliksman, Demers, \& Newton-Taylor (2001) and Shamsuddin et al. (2013) verified that high level of psychic suffering did not relate to the kind of dwelling. Murakami, Murray, Sims, \& Chedzey (2008) affirmed, by studying 35 British university students, that social competence has been studied, especially with children, in that manner the young adults' age group is neglected and, sometimes, evaluated out of context of professional practice, what justifies new studies with this population.

We verify, by analyzing the studies quoted, that in general they debated separately the academic variables and the socio-demographic variables and their relation with mental health or university students' social skills. In addition, the studies that differentiated men and women as for social skills did not control aspects regarding mental health. Therefore, such variables were seen as isolated subjects, however by the inclusion of one more variable simultaneously we could have a better understanding of complex phenomena, as in this study. We emphasize that, until what this research could reach, studies that approached the influences of academic and socio-demographic characteristics to social skills in students without mental disorder, systematically evaluated, were not identified, and this group may be consider a typical one.

In the same way, by controlling systematically the lack of mental health disorders, we intend to verify what is the role of academic and socio-demographic variables to the repertory of university student's social skills. We have by guiding hypothesis that by controlling mental health conditions, we will be able to verify how the socio-demographic and academic conditions influence social skills, as an university students' adaptation resource. We consider that the present study may contribute to compare data from two adaptive resources well known in the literature: mental health and social skills.

In conclusion, the present research has by objectives characterizing and comparing social skills of university students without mental health, according to academic and socio-demographic variables.

\section{Method}

\section{Participants}

In this study there were 461 university students without mental disorders that were systematically evaluated. They were undergraduate students from different courses of a public university, distributed in all years of their courses. The socio-demographic characteristics from the sample are: (a) 260 students enrolled in exact science courses, 199 in human science courses and 2 did not answer; (b) 245 from the first two years of their courses, 214 from intermediate / final years - $3^{\text {rd }}$, $4^{\text {th }}$ and $5^{\text {th }}$ years - and 2 did not answer; (c) 196 from full-time courses, 263 from evening courses and 2 did not answer; (d) 259 men, 201 women and 1 did not answer; (e) 180 employed, 277 unemployed and 4 did not answer; (f) 44 living by themselves, 199 with other students, 192 with their family, 11 with their boyfriend/ girlfriend and 13 with other people; (g) 441 were single, 12 married and 4 did not answer.

Regarding the sample path data had been taken from 609 university students that answered to the two instruments, as described in Instruments. The lack of indicators of any mental disorder evaluated by the structured clinic interview for the DSM-IV (SCID-I) was an essential criterion for the inclusion in the sample. 490 students were identified that fulfilled such criterion. It means that only $20 \%$ of the students did not fulfilled it, which is concordant with studies like those of Cerchiari et al. (2005) that found mental health issues prevalence in $25 \%$ of the university students evaluated.

Regarding the courses, even though data had been taken from the Biology course, it was excluded from the sample for being in a small number -22 participants. We have opted to work only with university students enrolled in exact science courses - Mathematics, 
Computer Science, Physics, Chemistry, Design, Information Systems and Civil, Electrical, Mechanical and Production Engineering - and in human science courses - Education, Architecture, Arts, Journalism, Radio and TV, Public Relations -, for having a larger number of evaluated courses. In this condition, 468 university students fulfilled the criterion.

In order to exclude from the sample university students with low academic performance, condition recognized as an adjustment indicator, another exclusion criterion was employed, defined as non-completion of the course within the pre-determined length of time established by the curriculum. For better understanding, there were eleven 4-year and six 5-year courses in the sample. The students that were attending a four years length course but were already in their fifth or sixth year in that course were excluded. The same happened with the students that were attending a five-year course for longer than that. Using this criterion seven university students were excluded. Considering all these criteria there were 461 participants in the study final sample.

\section{Instruments}

The instruments used were: Questionnaire of Social Abilities, Behaviors and Contexts Evaluation for University Students - QHC-Universitários (BolsoniSilva \& Loureiro, 2015) and Clinic Interview structured for the Diagnosis and Statistic Guide of Mental Disorders $4^{\circ}$ Ed. reviewed text - DSM-IV (Del-Ben and others, 2001).

Questionnaire of Social Abilities, Behaviors and Contexts Evaluation for University Students - QHCUniversitários: it is a questionnaire that evaluates social abilities, composed by questions that refer to the frequency and the way the participant behaves regarding their parents, friends, boyfriend/girlfriend, among others, as well as contexts where behaviors occur, the way the interlocutor reacts to their behaviors and the university students' feelings on those occasions. The instrument is constituted by the following topics: 1) Communication; 2) Expressiveness (positive and negative feelings and opinions); 3) Criticism (making and taking criticism); 4) Public speaking (speaking in public - known and unknown, frequency and difficulty to present seminars); and 5) Additional information (in case somebody would like to add something not mentioned in the questionnaire). The instrument was built having by theoretical frame of reference the Behavior Analysis, searching to describe situations, actions, consequences and associated feelings. All the items that compose it are discriminative of mental health from tracker and diagnosis instruments (BDI-Mini-Spin e SCID). The instrument is divided in two parts. The first one corresponds to the frequency that the evaluated behaviors show. They are organized according to three factors: Factor 1 Communication and affection (conversation, positive feelings, opinions); Factor 2 - Confrontation (negative feelings, making criticism, taking criticism); and Factor 3 - Public speaking (speaking in public and presenting seminars). The second part evaluates characteristics from these behaviors whose items - corresponding to situations/subjects, skillful behavior, unskillful behavior, positive consequences, negative consequences, positive feelings and negative feelings - constitute two factors denominated Potentialities and Difficulties. The study of the psychometric properties verified positive indicators of construct validity; converging, discriminating, and trustworthy (Bolsoni-Silva \& Loureiro, 2015). The test was attentive to the criterion for approval by the Psychological Federal Council.

Clinical Interview structured for the DSMIV (SCID-I - clinic version - Del-Ben et al., 2001): it was included in the study for being considered a mental health measurement that allows diagnostic classification by disturbance, as well as lack of psychiatric disturbance classification, being considered gold pattern in clinical studies. In this study, this clinical interview had the goal to exclude university students with any indicators of mental disorder from the sample. The clinical interview was proposed by First, Spitzer, Gibon, \& Willians (1997), translated and adapted to Portuguese by Del-Ben et al. (2001). It is used to elaborate psychiatric clinic diagnosis based on DSM-IV. Is composed by modules, ten in total, which may be applied in an independent or combined way, according to the evaluation objectives. According to Del-Ben and others (2001), the SCID presented satisfactory psychometric qualities.

\section{Procedures}

\section{Data Collection}

The data collection was collective and occurred after the Courses Coordination and respective professor's authorization. The university students were previously contacted in classrooms. The complete explanation about the research goals was given and the application date of the instruments was scheduled. The 
students that accepted to participate in the research signed an Informed Consent Form and received an explanatory letter about the project goals and a notebook containing instructions on the instruments application. A research auxiliary was available in the classroom to offer support to eventual doubts they could have. The SCID (Del-Ben et al., 2001) was later conducted by telephone by a previously trained professional, where the modules were applied.

\section{Data Analysis}

The data was compared (test $\mathrm{t}$ from Student) according to variables investigated: (a) exact sciences $\mathrm{x}$ human science courses; (b) first two years $\mathrm{x}$ intermediate/final years of their courses; (c) male $\mathrm{x}$ female university students; (d) employed $\mathrm{x}$ unemployed; (e) full-time $\mathrm{x}$ evening courses. As for the variable kind of dwelling (alone, family, boyfriend/girlfriend, with other students, etc.), a multivariate analysis was conducted first (ANOVA Oneway) and then, the behaviors that differentiated the groups were compared by the test $t$ from Student.

\section{Ethical Considerations}

This study is part of a larger project that proposes the evaluation and intervention related to the university students. The title of the project is Análise das habilidades sociais de grupos universitários and was approved on August $3^{\text {rd }}$ of 2007 by the Ethical In Research Committee of UNESP Bauru (process number 1315/46 /01/07).

\section{Results}

This section presents the results of the comparisons conducted: exact sciences $\mathrm{x}$ human science courses (Table 1); first two years $\mathrm{x}$ intermediate/final years of their courses (Table 2); male $\mathrm{x}$ female university students (Table 3); employed x unemployed (Table 4); full-time x evening courses (Table 5).

According to Table 1 the university students enrolled in human science courses presented higher social skill averages than the ones in exact science courses. They also presented higher average in frequency and regarding the diversity of the social skills evaluated, especially the ones of confrontation (expressing negative feelings, expressing opinions, making and taking criticism), as well as in expressing positive feelings and speaking in public (including presenting seminars). The university students enrolled in human science courses also presented higher averages in negative feelings associated to the expression of negative feelings and opinions.

According to Table 2 the university students from the first two years of their courses presented more difficulties - negative consequences and negative feelings - than those from the intermediate/ final years. The students from the first two years also presented more difficulties in having conversations, expressing opinions, making criticism and speaking in public. The ones from intermediate and final years reported more frequently speaking in public, as well as getting more positive consequences and the related positive feelings.

Table 3 makes the differences between men and women clear regarding their presented social skills, wherein women have more frequent behaviors than men. Women had, in higher averages, skills related to: expressing negative feelings, taking criticism, presenting seminars, confrontation, in a higher number of situations/subjects (Factor 2) and expressing the related positive feelings and positive consequences. However, they also evidenced more frequently unskillful behaviors and the reported negative feelings, especially when expressing opinions, making criticism and speaking in public. Men reported: (a) higher frequency of positive feelings than women; (b) fewer negative feelings expressed before many situations; (c) higher frequency of positive feelings when expressing opinions, making and taking criticism and also speaking in public and presenting seminars.

Examining Table 4 it is possible to verify that there are few items that tell the university students who work from those who do not work, and they are related to speaking in public skills. All the items with differences indicated that employed people reveal themselves more skillful.

The university students differ according to their kind of dwelling particularly regarding skillful behaviors and potentialities, and in a specific way as for the repertories of having conversations, expressing positive and negative feelings, opinions and making criticism. In sequence the analysis through test $t$ from Student was conducted, wherein the comparison between living by themselves or living with their family did not identify significant differences as for the repertory of social skills. In the comparison regarding living with other students and the other conditions some differences were identified and reported as follows:

(a) Living with other students (average/SD) $\mathrm{x}$ living with their family (average/SD): negative 
Table 1

QHC-Universitarios Categories in the Comparison between University Students of Exact Sciences and Human Science Courses

\begin{tabular}{|c|c|c|c|}
\hline \multirow{2}{*}{ QHC-Universitários Categories } & \multicolumn{3}{|c|}{ Human sciences } \\
\hline & \multicolumn{2}{|c|}{ Average (standard deviation) } & $t^{* *}$ \\
\hline \multicolumn{4}{|c|}{ QHC-Universitários - Behavior Frequencies - Part 1} \\
\hline Expressing negative feelings & $2.80(2.32)$ & $3.63(2.36)$ & $-3.738^{* *}$ \\
\hline Making criticism & $0.80(0.92)$ & $1.03(0.95)$ & $-2.564^{*}$ \\
\hline Taking criticism & $2.83(1.86)$ & $3.57(1.93)$ & $-4.112 * *$ \\
\hline Speaking in public & $2.35(1.20)$ & $2.68(1.04)$ & $-7.383 * *$ \\
\hline Presenting seminars & $1.88(1.10)$ & $2.61(1.02)$ & $-3.197 * *$ \\
\hline Factor 2 - expressiveness & $6.44(3.97)$ & $8.23(4.09)$ & $-4.70 * *$ \\
\hline Factor 3 - speaking in public & $4.23(1.82)$ & $5.30(1.71)$ & $-6.43^{* *}$ \\
\hline \multicolumn{4}{|c|}{ QHC-Universitários - Behavior Characteristics - Part 2} \\
\hline Situations/subjects & $21.80(8.09)$ & $23.71(8.48)$ & $-2.438^{*}$ \\
\hline Skillful behaviors & $15.71(5.48)$ & $17.29(5.23)$ & $-3.144 * *$ \\
\hline Negative feelings & $11.94(11.06)$ & $14.7(12.52)$ & $-2.472 *$ \\
\hline Difficulties & $19.30(14.67)$ & $22.8(16.02)$ & $-2.466^{* *}$ \\
\hline \multicolumn{4}{|c|}{ QHC-Universitários - Behavior Characteristic Items - Part 2} \\
\hline Expressing positive feelings - skillful behaviors & $6.67(3.54)$ & $7.36(3.50)$ & $-2.075^{*}$ \\
\hline Expressing positive feelings - positive consequences & $3.65(1.15)$ & $3.91(0.93)$ & $-2.697 * *$ \\
\hline Expressing positive feelings - positive feelings & $8.48(4.33)$ & $9.24(3.98)$ & $-1.959 *$ \\
\hline Expressing negative feelings - situations & $2.42(2.41)$ & $3.22(2.60)$ & $-3.369 * *$ \\
\hline Expressing negative feelings - skillful behaviors & $0.93(1.15)$ & $1.21(1.11)$ & $-2.560 * *$ \\
\hline Expressing negativef - negative feelings & $1.66(2.44)$ & $2.36(2.95)$ & $-2.740 * *$ \\
\hline Expressing opinions - positive feelings & $6.20(5.06)$ & $4.99(4.81)$ & $2.593 * *$ \\
\hline Expressing opinions - negative feelings & $1.12(1.88)$ & $1.61(2.33)$ & $-2.445^{*}$ \\
\hline Making criticism - situations & $3.98(2.41)$ & $4.53(2.58)$ & $-2.352 *$ \\
\hline Making criticism - negative feelings & $1.39(2.13)$ & $2.05(2.74)$ & $-2.772 * *$ \\
\hline Taking criticism - skillful behaviors & $2.05(1.34)$ & $2.29(1.32)$ & $-1.966 *$ \\
\hline Presenting seminars - negative feelings & $1.47(1.47)$ & $1.79(1.49)$ & $-2.314^{*}$ \\
\hline
\end{tabular}

The differences correspond to $p \leq 0.01^{(*)}$ e $p \leq 0.05^{(*)}$. Results that express statistically differences significance.

feelings - skillful behaviors $(1.28 / 1.24 \times 0.92 / 1.03, p$ $=0.002)$; expressing opinions - situations $(4.47 / 2.26$ $\mathrm{x} 3.23 / 1.89, p=0.000)$; expressing opinions - positive feelings $(6.50 / 5.44 \times 4.78 / 4.44, p=0.001)$; making criticism - situations $(4.87 / 2.59 \times 3.68 / 2.23, p=$ $0.000)$; making criticism - positive feelings $(5.90 / 4.99$ $\mathrm{x} 4.77 / 4.84, p=0.023)$; making criticism - frequency $(1.21 / 0.98 \times 0.64 / 0.80, \mathrm{p}=0.000)$; factor $2-$ confrontation $(7.93 / 4.08 \times 6.64 / 4.08, p=0.002)$; skillful behavior total $(16.98 / 5.31 \times 15.71 / 5.51, p=0.021)$; potentialities $(105.26 / 35.08 \times 97.35 / 32.03, p=0.020)$. The results from the comparison between university students living with other students or living with their family showed that the first ones were more skillful in the expression of negative feelings, positive feelings, making criticism and in skillful behaviors and potentialities (the sum of skillful behaviors, positive feelings and positive consequences).

(b) Living with other students (average/SD) $\mathbf{x}$ living by themselves (average/SD): negative feelings - skillful behaviors (1.28/1.24 x 0.82/1.02, $p=0.011)$; expressing opinions - positive feelings $(6.50 / 5.44 \mathrm{x}$ 5.07/4.01, $p=0.049)$; making criticism - situations $(4.87 / 2.59 \times 3.59 / 2.40, p=0.002)$; making criticism 
Table 2

QHC-Universitários Categories in the Comparison between University Students from the First Two Years and from Intermediate/ Final Years of their Courses

\begin{tabular}{|c|c|c|c|}
\hline \multirow[t]{2}{*}{ QHC-Universitários Categories } & First two years & $\begin{array}{c}\text { Intermediate/ } \\
\text { final years }\end{array}$ & \\
\hline & \multicolumn{2}{|c|}{ Average (standard deviation) } & $t^{* *}$ \\
\hline \multicolumn{4}{|c|}{ QHC-Universitários - Behavior Frequencies - Part 1} \\
\hline Presenting seminars & $2.00(1.11)$ & $2.42(1.10)$ & $-4.104 * *$ \\
\hline Factor 3 - speaking in public & $4.40(1.78)$ & $5.02(1.88)$ & $-3.584 * *$ \\
\hline \multicolumn{4}{|c|}{ QHC-Universitários - Behavior Characteristics - Part 2} \\
\hline Unskillful behaviors & $5.75(3.65)$ & $5.04(3.53)$ & $2.119^{*}$ \\
\hline Negative feelings & $14.52(13.07)$ & $11.56(9.90)$ & $2.757 * *$ \\
\hline Difficulties & $22.72(16.63)$ & $18.73(13.46)$ & $2.843^{* *}$ \\
\hline \multicolumn{4}{|c|}{ QHC-Universitários - Behavior Characteristic Items - Part 2} \\
\hline Having conversations - negative consequences & $0.69(1.12)$ & $0.51(0.89)$ & $1.995^{*}$ \\
\hline Having conversations - negative feelings & $2.58(3.40)$ & $1.94(2.49)$ & $2.337 *$ \\
\hline Opinions - negative feelings & $1.58(2.35)$ & $1.05(1.74)$ & $2.763^{*}$ \\
\hline Making criticism - negative feelings & $1.98(2.71)$ & $1.33(2.03)$ & $2.893^{* *}$ \\
\hline Presenting seminars - situations & $0.69(0.73)$ & $0.87(0.76)$ & $-2.596^{* *}$ \\
\hline Presenting seminars - skillful behaviors & $0.59(0.76)$ & $0.76(0.80)$ & $-2.347 *$ \\
\hline Presenting seminars - positive consequences & $1.09(0.63)$ & $1.38(0.62)$ & $-4.842^{* *}$ \\
\hline Presenting seminars - positive feelings & $0.90(1.10)$ & $1.12(1.17)$ & $-2.055^{*}$ \\
\hline Speaking in public - situations & $2.20(1.09)$ & $2.39(1.03)$ & $-1.921 *$ \\
\hline Speaking in public - skillful behaviors & $1.84(1.23)$ & $2.18(1.23)$ & $-2.891 * *$ \\
\hline Speaking in public - unskillful behaviors & $1.56(1.33)$ & $1.20(1.29)$ & $2.941 * *$ \\
\hline Speaking in public - positive consequences & $3.01(1.47)$ & $3.40(1.55)$ & $-2.741 * *$ \\
\hline Speaking in public - negative feelings & $1.78(1.72)$ & $1.48(1.58)$ & $1.929 * *$ \\
\hline
\end{tabular}

The differences correspond to $p \leq 0.01^{(*)}$ e $p \leq 0.05^{(*)}$. Results that express statistically differences significance.

- frequency $(1.21 / 0.98 \times 0.52 / 0.73, p=0.000)$; factor 2 - confrontation $(7.93 / 4.08 \times 6.34 / 3.77, p=0.015)$. The results from the comparison between university students living with other students or living by themselves showed that the first ones were more skillful in confrontation behaviors, in such case, the expression of negative feelings, the expression opinions and handling criticism.

The comparison between full-time and evening courses indicated that the evening course students presented more speaking in public skills. The group of university students in full-time courses evidenced more skills in confrontation behaviors - expressing opinions and making criticism -, in frequency, as well as in the positive consequences and in the positive feelings associated.

\section{Discussion}

In the data analysis the influence of socio-demographic variables and course academic characteristics will be considered for the repertory of social skills, as an adaptation resource of university students without mental disorders. We were able to verify, according to literature findings (Al-Alawneh et al., 2011; Bolsoni-Silva et al., 2010), that university students from intermediate/final years of their courses were more skillful than those from the first two years, regarding having conversation skills and confrontation - handling criticism and speaking in public. The present investigation advanced in relation to previous studies as to evaluate students from the first till fifth year and not only until third year (Bolsoni-Silva et al., 2010), or second year of the 
Table 3

QHC-Universitários Categories in the Comparison between Male and Female University Students

\begin{tabular}{|c|c|c|c|}
\hline \multirow{2}{*}{ QHC-Universitários Categories } & Men & Women & \\
\hline & \multicolumn{2}{|c|}{ Average (standard deviation) } & $t^{*}$ \\
\hline \multicolumn{4}{|c|}{ QHC-Universitários - Behavior Frequencies - Part 1} \\
\hline Expressing negative feelings & $2.85(2.25)$ & $3.57(2.46)$ & $-3.205^{* *}$ \\
\hline Taking criticism & $2.94(1.88)$ & $3.41(1.95)$ & $-2.607 * *$ \\
\hline Presenting seminars & $2.09(1.12)$ & $2.34(1.11)$ & $-2.388 * *$ \\
\hline Factor 2 - confrontation & $6.67(3.90)$ & $7.93(4.27)$ & $-3.261 * *$ \\
\hline \multicolumn{4}{|c|}{ QHC-Universitários - Behavior Characteristics - Part 2} \\
\hline Situations/subjects & $21.83(8.41)$ & $23.62(8.08)$ & $-2.317^{*}$ \\
\hline Unskillful behaviors & $4.80(3.49)$ & $6.18(3.62)$ & $-4.123^{* *}$ \\
\hline Positive feelings & $38.11(20.14)$ & $33.80(17.88)$ & $2.431 * *$ \\
\hline Negative feelings & $11.57(11.26)$ & $15.11(12.15)$ & $-3.199 * *$ \\
\hline Difficulties & $18.65(14.59)$ & $23.63(15.88)$ & $-3.456^{* *}$ \\
\hline \multicolumn{4}{|c|}{ QHC-Universitários - Behavior Characteristic Items - Part 2} \\
\hline Positive feelings - skillful behaviors & $6.64(3.62)$ & $7.38(3.40)$ & $-2.268^{*}$ \\
\hline Positive feelings - positive consequences & $3.67(1.11)$ & $3.88(1.00)$ & $-2.127^{*}$ \\
\hline Negative feelings - situations & $2.41(2.35)$ & $3.22(2.66)$ & $-3.414 * *$ \\
\hline Negative feelings - unskillful behaviors & $0.95(1.22)$ & $1.36(1.43)$ & $-3.270 * *$ \\
\hline Negative feelings - negative feelings & $1.70(2.52)$ & $2.28(2.87)$ & $-2.268^{*}$ \\
\hline Expressing opinions - unskillful behaviors & $0.34(0.64)$ & $0.48(0.75)$ & $-2.181 *$ \\
\hline Expressing opinions - positive feelings & $6.32(5.11)$ & $4.85(4.69)$ & $3.196 * *$ \\
\hline Expressing opinions - negative feelings & $1.11(1.91)$ & $1.61(2.29)$ & $-2.496 * *$ \\
\hline Making criticism - unskillful behaviors & $0.32(0.61)$ & $0.47(0.69)$ & $-2.337^{*}$ \\
\hline Making criticism - positive feelings & $5.85(4.71)$ & $4.71(4.94)$ & $2.524 * *$ \\
\hline Making criticism - negative feelings & $1.35(2.15)$ & $2.09(2.70)$ & $-3.221 * *$ \\
\hline Taking criticism - positive feelings & $3.04(3.87)$ & $2.11(3.25)$ & $2.795^{* *}$ \\
\hline Presenting seminars - unskillful behaviors & $1.61(1.32)$ & $1.99(1.32)$ & $-3.092 * *$ \\
\hline Presenting seminars - positive feelings & $1.14(1.19)$ & $0.83(1.04)$ & $2.949 * *$ \\
\hline Presenting seminars - negative feelings & $1.41(1.47)$ & $1.88(1.46)$ & $-3.397 * *$ \\
\hline Speaking in public - unskillful behaviors & $1.28(1.33)$ & $1.51(1.31)$ & $3.334 * *$ \\
\hline Speaking in public - positive feelings & $2.85(1.98)$ & $2.06(1.80)$ & $4.476^{* *}$ \\
\hline Speaking in public - negative feelings & $1.42(1.65)$ & $1.91(1.63)$ & $-3.132 * *$ \\
\hline
\end{tabular}

The differences correspond to $p \leq 0.01^{(*)}$ e $p \leq 0.05^{(*)}$. Results that express statistically differences significance.

courses (Al-Alawneh et al., 2011), allowing to a better understanding of the influence of the graduation years in the repertory of social skills.

The findings of the present research were also concordant with the study of Al-Alawneh et al. (2011), in which students of human sciences revealed themselves more skillful than those from exact sciences.
Based on the instrument used we identified that these human science students were more skillful above all in confrontation, expressing positive feelings and speaking in public skills. Such results may have been obtained because, usually, these courses stimulate group work and seminar presentations that can be effective to training these behaviors. However, the human science 
Table 4

QHC-Universitários Categories in the Comparison between University Students Regarding Employment and Dwelling

\begin{tabular}{|c|c|c|c|}
\hline \multirow{2}{*}{ QHC-Undergraduates Categories } & Employed & Unemployed & $t^{* *}$ \\
\hline & \multicolumn{2}{|c|}{ Average (standard deviation) } & \\
\hline \multicolumn{4}{|c|}{ QHC-Undergraduates - Behavior Frequencies - Part 1} \\
\hline Speaking in public & $2.63(1.15)$ & $2.39(1.13)$ & $2.156^{*}$ \\
\hline Presenting seminars & $2.51(1.08)$ & $1.98(1.10)$ & $5.044 * *$ \\
\hline Factor 3 - Speaking in public & $5.1(1.84)$ & $4.37(1.79)$ & $4.369 * *$ \\
\hline \multicolumn{4}{|c|}{ QHC-Undergraduates - Behavior Characteristic Items - Part 2} \\
\hline Presenting seminars - situations & $0.88(0.77)$ & $0.70(0.72)$ & $2.499 * *$ \\
\hline Presenting seminars - skillful behaviors & $0.80(0.81)$ & $0.58(0.75)$ & $2.892^{* *}$ \\
\hline Presenting seminars - unskillful behaviors & $1.57(1.20)$ & $1.91(1.39)$ & $-2.738^{* *}$ \\
\hline Presenting seminars - positive consequences & $1.37(0.62)$ & $1.13(0.64)$ & $4.054^{* *}$ \\
\hline Presenting seminars - positive feelings & $1.29(1.20)$ & $0.82(1.06)$ & $4.356^{* *}$ \\
\hline Speaking In Public - skillful behaviors & $2.14(1.26)$ & $1.91(1.21)$ & $1.928^{*}$ \\
\hline Speaking In Public - positive consequences & $3.41(1.60)$ & $3.04(1.44)$ & $2.486^{* *}$ \\
\hline Kind of dwelling & Medium & & $\mathrm{F}^{* *}$ \\
\hline \multicolumn{4}{|c|}{ QHC-Universitários - Behavior Frequencies - Part 1} \\
\hline Making criticism & 10.595 & & $13.398^{* *}$ \\
\hline Factor 2 - Confrontation & 65.550 & & $3.980 * *$ \\
\hline \multicolumn{4}{|c|}{ QHC-Universitários - Behavior Characteristics - Part 2} \\
\hline Factor 1 - Potentialities & 2824.635 & & $2.535^{*}$ \\
\hline \multicolumn{4}{|c|}{ QHC-Universitários - Behavior Characteristic Items - Part 2} \\
\hline Having conversations - situations & 15.516 & & $2.354^{*}$ \\
\hline Having conversations - positive consequences & 27.608 & & $2.929 *$ \\
\hline Positive Feelings - skillful behaviors & 59.612 & & $4.915^{* *}$ \\
\hline Negative Feelings - skillful behaviors & 4.831 & & $3.819^{* *}$ \\
\hline Expressing Opinions - situations & 42.336 & & $9.637 * *$ \\
\hline Expressing Opinions - positive feelings & 102.632 & & $4.253^{* *}$ \\
\hline Making criticism - situations & 39.809 & & $6.667 * *$ \\
\hline Making criticism - positive feelings & 56.843 & & $2.456^{*}$ \\
\hline Skillful behavior total & 77.925 & & $2.691 *$ \\
\hline
\end{tabular}

The differences correspond to $p \leq 0.01^{(*)}$ e $p \leq 0.05^{(*)}$. Results that express statistically differences significance.

students presented indicators of not feeling well in the expression of negative feelings and opinions. This denotes a level of difficulty of proficiency in the use of those skills to resolve problems. Such data suggests the relevance of social skill systematic teaching for university students, especially for those of exact sciences, which countersigns the proposition made by Murakami et al. (2008), as to point the role of the University in promoting the teaching of such skills. As for the course shift, the evening course students revealed themselves more skillful to speak in public than those from full-time courses, probably because the evening courses are attended, over all, by employed students that seems to stimulate such repertory. Nevertheless, the full-time course students were more skillful in confrontation behaviors - expressing opinions and making criticism - both in frequency as well as in the positive consequences and the related positive feelings, which 
Table 5

QHC-Universitários Categories in the Comparison between University Students from Full-Time and Evening Courses

\begin{tabular}{|c|c|c|c|}
\hline \multirow{2}{*}{ QHC-Universitários Categories } & Full-Time courses & Evening courses & \\
\hline & \multicolumn{2}{|c|}{ Average (standard deviation) } & $t^{* *}$ \\
\hline \multicolumn{4}{|c|}{ QHC-Universitários - Behavior Frequencies - Part 1} \\
\hline Expressing opinions & $6.89(2.28)$ & $6.32(2.50)$ & $2.548^{* *}$ \\
\hline Making criticism & $1.03(1.00)$ & $0.81(0.87)$ & $2.402 *$ \\
\hline Presenting seminars & $2.04(1.11)$ & $2.31(1.12)$ & $-2.631 * *$ \\
\hline \multicolumn{4}{|c|}{ QHC-Universitários - Behavior Characteristic Items - Part 2} \\
\hline Negative feelings - skillful behaviors & $1.19(1.21)$ & $0.94(1.07)$ & $2.346^{*}$ \\
\hline Expressing opinions - situations & $4.13(2.22)$ & $3.58(2.10)$ & $2.705^{* *}$ \\
\hline Expressing opinions - skillful Behaviors & $1.88(1.04)$ & $1.70(0.54)$ & $2.242^{*}$ \\
\hline Expressing opinions - positive feelings & $6.32(5.31)$ & $5.22(4.68)$ & $2.299 *$ \\
\hline Making criticism - situations & $4.55(2.57)$ & $3.97(2.43)$ & $2.473 * *$ \\
\hline Making criticism - skillful behaviors & $1.88(1.04)$ & $1.70(0.54)$ & $2.242^{*}$ \\
\hline Making criticism - positive feelings & $6.04(5.55)$ & $4.87(4.18)$ & $2.482^{* *}$ \\
\hline Presenting seminars - skillful Behaviors & $0.58(0.74)$ & $0.75(0.81)$ & $-2.332^{*}$ \\
\hline Presenting seminars - positive feelings & $0.87(1.08)$ & $1.11(1.17)$ & $-2.335^{*}$ \\
\hline
\end{tabular}

The differences correspond to $p \leq 0.01^{(*)}$ e $p \leq 0.05^{(*)}$. Results that express statistically differences significance.

corroborates with what was reported by Bolsoni-Silva et al. (2010).

Regarding the demographic variables in relation to gender, the results suggest that men and women present distinctive repertory of social skills, as marked by other studies (Al-Alawneh et al., 2001; Avsar \& Kuter, 2007; Bolsoni-Silva et al., 2010). As for frequency in social skills, women showed themselves more skillful in expressing positive feelings, negative feelings, taking criticism and presenting seminars, as reported in the study of Ozben (2013).

We emphasize that the skill of expressing positive feelings favors adaptation; on the other hand, women also reported the related negative feelings, over all when expressing opinions, making criticism and speaking in public. We might think, before this supposed contradiction, that women may be expressing themselves in a skillful way, but the interlocutors do not value that because the behaviors of expressing opinions, making criticism and speaking in public are more typically expected from men, since they involve leadership, as demonstrated by Al-Alawneh et al. (2011). Another hypothesis would be that women may be trying to express themselves but they do it in an unskillful way. Accordingly, as the studied data was obtained through self-report, we were not able to access the manner of expression, which could have been evaluated by direct observation. This point could be object for new researches.

Regarding men, we confirmed that they reported: (a) higher frequency of expressing positive feelings than women; (b) expressing negative feelings before many situations; (c) having positive feelings when expressing opinions, making and taking criticism and also speaking in public. These findings contradict the literature with regard to expressing positive feelings (Avsar \& Kuter, 2007; Bolsoni-Silva et al., 2010), expressiveness and speaking in public (Bolsoni-Silva et al., 2010), but confirm previous findings that indicate that men and women may be more skillful in distinct behaviors (Al-Alawneh et al., 2011; Avsar \& Kuter, 2007; BolsoniSilva et al., 2010).

The variable kind of dwelling also presented a peculiar data, since the university students living with other students were more skillful than those living with their families or by themselves, contradicting with the research of Cerchiari et al. (2005), which appointed that living with their family protected the student from mental health disorders, refuting Adlaf et al. (2001) that did not verify the relation between mental health and kind of dwelling. We can think that the specific characteristic of the sample of the present research, university 
students without mental health disorders that were systematically evaluated, favored such data. Therefore we might think that university students with mental health disorders may be more comfortable living with their families in comparison to living with other students, which seems to have an atmosphere that demands more interpersonal tasks.

Regarding the variable employed or unemployed students, what really differentiated the groups was the speaking in public skills, more frequent among those who were employed. Cerchiari et al. (2005) identified that a payment work was a protection factor for student's health. This variable regarding social skills also demonstrated that working promotes social skills, but not them all, only as for speaking in public.

Analyzing this study dataset we could verify that even controlling the variable of lack of mental disorder, the university students presented a few difficulties as for social skills. According to the guiding hypothesis of the study, we could verify that the socio-demographic condition and academic condition influenced the social skills, as adaptation source of university students. Besides, we could examine that social skills and mental health indicators responded by specific aspects, as adaptive sources, which suggests the necessity of an independent evaluation of these two variables.

Once the experiences in the university context are for the adults, the identification of university students without mental disorders but with difficulties as for social skills, suggests the necessity of universal preventive practices. Accordingly, the proposition of preventive programs would be appropriate, as an offer of supporting services to students' communities, even before they search for the university school clinic, when facing adaptive difficulties. Such proposition is in agreement with Peres, Santos and Coelho (2004) when they say that offering an attendance service to this population would be part of the University duty, in a way of valuing the students' development potential. In order to illustrate such proposition, the study of Bolsoni-Silva et al. (2010) can be mentioned. This study divulged and realized a group attendance to university students, offering the promotion of social skills as a modality of prevention. The promotion happened through the university radio, posters broadcast throughout campus and classroom visits. The difficulties regarding social interactions with different interlocutors - family, boyfriend/ girlfriend, colleagues and friends -, were among the reasons that took students to positively respond to this proposition. Such difficulties had themes like speaking in public, romantic relationships, family relationships and friendship, as well as making new friends. These complaints had already been documented in several studies (Del et al., 2006). We consider that improving the skill repertories to diverse interactions may promote a better adaptation in that life moment of young university students.

\section{Closing Remarks}

The present research was conducted with a sample of university students systematically evaluated, without mental disorders, and which presented associated peculiarities in socio-demographic variables and graduation course characteristics related to social skills. In a generally manner, the university students that showed themselves socially skillful were those in human science, full-time courses, in the intermediate/final years and female. However, evening course students and those who worked showed more skills as for speaking in public. Living with other students also seemed to promote social skills, particularly those of confrontation.

We emphasize that only part of the evaluated behaviors told the groups apart, indicating that, regarding social skills, there are potentialities and difficulties for all university students, and that universal preventive programs have their applicability, even with students without mental disorders. Such data proves to be the main study contribution, showing social skill peculiarities opposing to mental heath, both variables, related to adaptive sources, but with diverse characteristics that justify being considered independently.

Methodologically speaking, the study strongest point, which is inserted in a lack of literature, was to include only university students without mental disorders, which were systematically evaluated. This allowed confronting such variable, which is widely known as an adaptive source, to social skills also known as favorer of adaptation and quality of life. We may include as limitations: a) the cross-sectional that did not allow evaluating university students through academic life, not making it clear if the sources or deficits modify through time; b) the lack of a systematic evaluation of academic performance through graduation, excluding only the students that already exceeded the pre-determined length of time established by the curriculum in the moment of data collection, may included students with academic difficulties that still did not exceed that pre-determined length of time.

The necessity of diversifying the sample is highlighted as perspective for new researches, including 
more public and private universities, biological science courses, and from different locations in the country. We could also include observation measures, besides self-report, as perspective for new researches. We consider that the interfaces between social skills and mental health are in need of new studies that compare different clinical groups, in a way of exploring superposition and point differentiations, which will enable us to implement prevention and intervention programs.

\section{References}

Adlaf. E. M., Gliksman. L., Demers. A., \& NewtonTaylor. B. (2001).The prevalence of elevated psychological distress among Canadian undergraduates: Findings from the 1998 canadian campus survey. Journal of American College Health. 50(2). 6772. doi: 10.1080/07448480109596009

Al-Alawneh. M. K., Meqdadi. R., Al-Refai. A., Khdair. R., \& Malkawi. A. (2011). Examining the effect of college type, study level, and gender of students on their use of teamwork skills as they perceived at yarmouk university of jordan. Canadian Social Science. 7(6). 48-57. doi: 10.3968/1923669720110706.282

Avşar. Z., \& Kuter. F. O. (2007). Determination of social skills level in students of uludag university physical education and sports department. Journal of Theory and Practice in Education. 3(2). 197-206. Retrieved from http://eku.comu.edu.tr/index/3/2/ zavsar_fokuter.pdf

Backer. S. R. (2003). A prospective longitudinal investigation of social problem- solving appraisals on adjustment to university. stress. health and academic motivation and performance. Personality and Individual Differences. 35(3). 569-591. doi:10.1016/ S0191-8869(02)00220-9

Bandeira. M., Rocha. S. S., Freitas. L. C., Del Prette. Z. A. P., \& Del Prette. A. (2006). Habilidades sociais e variáveis sociodemográficas em estudantes do ensino fundamental. Psicologia em Estudo. 11(3). 541-549. Retrieved from http://www.scielo.br/ $\mathrm{pdf} / \mathrm{pe} / \mathrm{v} 11 \mathrm{n} 3 / \mathrm{v} 11 \mathrm{n} 3 \mathrm{a} 09 . \mathrm{pdf}$

Bolsoni-Silva. A. T., \& Loureiro. S. R. (2015). Questionário de avaliação de habilidades sociais, comportamentos e contextos para universitários (QHC-Universitários). Manual Técnico. CETEPP
- Centro Editor de Testes e Pesquisa em Psicologia pela tradução em língua portuguesa. 2015.

Bolsoni-Silva. A. T., Loureiro. S. R., Rosa. C. F., \& Oliveira. M. C. F. A. (2010). Caracterização das habilidades sociais de universitários. Contextos Clínicos. 3(1). 62-75. doi: 10.4013/ctc.2010.31.07

Cerchiari. E. A. N., Caetano. D., \& Faccenda. O. (2005). Prevalência de transtornos mentais menores em estudantes universitários. Estudos de Psicologia (Natal). 10(3). 413-420. doi: 10.1590/ S1413-294X2005000300010

Del Prette. Z. A. P., \& Del Prette. A.. (2013). Social skills inventory (SSI-Del- Prette): Characteristics and studies in Brazil. In Osório. F. L (Org.) Social Anxiety Disorders (pp. 47-62). New York: Nova Science Publishers. Inc.

Del Prette. Z. A. P., Del Prette. A., \& Barreto. M. C. M. (2006). Treinamento de habilidades sociais em grupo com estudantes de Psicologia: Avaliando um programa de intervenção. In M. Bandeira. Z. A. P. Del Prette. \& A. Del Prette (Ed.). Estudos sobre habilidades sociais e relacionamento interpessoal (pp. 217234). São Paulo: Casa do Psicólogo.

Del-Ben. C. M., Vilela. J. A. A., Crippa. J. A. S., Hallak. J. E. C., Labate. C. M., \& Zuardi. A. W. (2001). Confiabilidade da "entrevista clínica estruturada para o DSM-IV - Versão Clínica" traduzida para o português. Revista Brasileira de Psiquiatria. 23(3). 156-159. doi: 10.1590/S1516-44462001000300008

Facundes. V. L. D., \& Ludermir. A. B. (2005). Common mental disorders among health care students. Revista Brasileira de Psiquiatria. 27(3). 194-200. doi: 10.1590/S1516-44462005000300007

First. M. B., Spitzer. R. L., Gibon. M., \& Willians. J. B. W. (1997). Structured clinical interview for DSM-IV Axis I disorders - Clinican Version (SCID-CV). Washington. DC: American Psychiatric Press.

Hussain. R., Guppy. M., Robertson. S., \& Temple. E. (2013). Physical and mental health perspectives of first year undergraduate rural university students. BMC public health. 13. 848-858. doi:10.1186/1471-2458-13-848

Johansson. R., Carlbring. P., Heedman. A., Paxling. B., Andersson. G. (2013). Depression, anxiety and their comorbidity in the swedish general population: point prevalence and the effect on health-related 
quality of life. Peer Journal. 1. 1-18. doi: 10.7717/ peerj.98.

Murakami. K., Murray. L., Sims. D., \& Chedzey. K. (2008). Learning on work placement: The narrative development of social competence. Journal Adult Development. 16(1). 13-24. doi: 10.1007/ s10804-008-9044-9

Neves. M. C. C., \& Dalgalarrondo. P. (2007). Transtornos mentais autorreferidos em estudantes universitários. Jornal Brasileiro de Psiquiatria. 56(4). 237-244. doi: 10.1590/S0047-20852007000400001

Ozben. S. (2013). Social skills, life satisfaction, and loneliness in Turkish university students. Social Behavior and Personality: An international journal. 41(2). 203-211. doi: 10.2224/sbp.2013.41.2.203

Peres. R. S., Santos. M. A., \& Coelho. H. M. B. (2004). Perfil da clientela de um programa de pronto-atendimento psicológico a estudantes universitários. Psicologia em Estudo. 9(1). 47-54. Retrieved from http://www.scielo.br/pdf/pe/v9n1/v9n1a07

Ramírez. M. T. G., Hernández. R. L., \& García-Campayo. J. (2009). Relación entre la depresión, la ansiedad y los sintomas psicosomáticos en uma muestra de estudiantes universitarios del norte de México. Revista Panamericana Salud Publica. 25(2). 141-145. doi:10.1590/S1020-49892009000200007

Ribeiro. D., \& Bolsoni-Silva. A. T. (2011). Potencialidades e dificuldades interpessoais de universitários: Estudo de caracterização. Revista Acta Comportamentalia. 19(2). 205-224. Retrieved from http:// pepsic.bvsalud.org/scielo.php?pid $=$ S0188$-81452011000200005 \&$ script $=$ sci_arttext

Shamsuddin. K., Fadzil. F., Ismail. W. S. W., Shah. S. A., Omar. K.. Muhammadc. N. A., Jaffar. A., Ismail. A., \& Mahadevan. R. (2013). Correlates of depression, anxiety and stress among Malaysian undergraduate students. Asian Journal of Psychiatry. 6. 318-323. doi: 10.1016/j.ajp.2013.01.014

Wristen. B. G. (2013). Depression and Anxiety in university music students. Applications of Research in Music Education. 31(2). 20-27. doi: $10.1177 / 8755123312473613$

Recebido: 10/04/2014 Primeira reformulação: 22/12/2014 Segunda reformulação: 05/02/2015 Aprovado: 18/02/2015

Sobre as autoras:

Alessandra Turini Bolsoni-Silva é psicóloga, professora adjunta da Faculdade de Ciências/UNESP e docente nos cursos de Psicologia e Pós-Graduação em Psicologia do Desenvolvimento e Aprendizagem. Trabalha com Análise Aplicada do Comportamento em Psicologia Clínica e em Psicologia do Desenvolvimento em diferentes temáticas: habilidades sociais, habilidades sociais educativas parentais e de professores, relacionamento conjugal, problemas de comportamento infantil, transtornos de ansiedade e depressão.

E-mail: bolsoni@fc.unesp.br

Sonia Regina Loureiro é psicóloga, professora doutora da Faculdade de Medicina de Ribeirão Preto/USP e docente nos cursos de pós-graduação em Saúde Mental e Psicologia. Coordena o Serviço de Avaliação Psicológica e desenvolve atividades de pesquisa com instrumentos e procedimentos de avaliação em diferentes contextos psicossociais. E-mail: srlourei@fmrp.usp.br

Contato com as autoras:

Alessandra Turini Bolsoni-Silva

E-mail: bolsoni@fc.unesp.br

Av. Affonso José Aiello, 8-200, Casa F-10, Vila Aviação, Condomínio Villágio 3

CEP: 17018-520 - Bauru/SP

Psico-USF, Bragança Paulista, v. 20, n. 3, p. 447-459, set./ dez. 2015 
